\title{
The influence of preoperative pharmacotherapy on the appearance of postoperative atrial fibrillation in patients undergoing isolated coronary artery bypass grafting
}

\author{
Milica V. Vukicevic ${ }^{1}$, Svetozar Putnik ${ }^{2,3}$, Tatjana S. Potpara ${ }^{1,3}$ \\ ${ }^{1}$ Cardiology Clinic, Clinical Centre of Serbia, ${ }^{2}$ Cardiac Surgery Clinic, Clinical Centre of Serbia, ${ }^{3}$ School of Medicine, Belgrade \\ University, Belgrade, Serbia
}

Abstract

Introduction: Postoperative atrial fibrillation (POAF) is the most common arrhythmia post coronary artery bypass grafting (CABG). It is associated with an increased morbidity and mortality. Published studies have yielded conflicting results considering the association of preoperative pharmacotherapy with POAF. We assessed the relationship of preoperative medication with POAF in patients undergoing isolated CABG.

Methods: We retrospectively studied 226 consecutive patients without history of prior AF, undergoing CABG from September to December 2014. All patients underwent continuous telemetry for $\geq 5$ postoperative days, and POAF was documented using 12-channel electrocardiography. We used univariate and multivariable Logistic regression analyses (adjusted for demographics, cardiovascular risk factors, and the CABG procedure type) to analyse the relationship of preoperative pharmacotherapy with the occurrence of POAF.

Results: Of 226 patients (mean age: 63.9 $\pm 7.9 y e a r s$, female $n=54,23.9 \%), 53$ (23.5\%) experienced $\geq 1$ POAF episode until discharge. They were older (65.8 \pm 7.3 vs. $63.4 \pm 8.0 ; p=0.049)$ and less often were taking statins preoperatively compared to non-POAF patients ( $n=39,73.6 \%$ vs. $n=137,87.2 \%$; $p=0.030$ ). There were no significant differences between the groups considering concomitant preoperative comorbidities (e.g., arterial hypertension, diabetes mellitus, chronic obstructive pulmonary disease, etc.), smoking or preoperative medication including amiodarone, beta-blockers, digoxin, diuretics, spironolactone, angiotensin-converting enzyme inhibitors or angiotensin II receptor blockers and $\mathrm{Ca}$-antagonists. In a multivariable analysis, preoperative statin use was associated with a $60 \%$ risk reduction in POAF incidence (Odds Ratio 0.41; $95 \% \mathrm{Cl} 0.19-0.87 ; \mathrm{p}=0.020$ ).

Conclusion: We found that preoperative use of statins may reduce the incidence of POAF in patients undergoing isolated CABG.

Key Words postoperative atrial fibrillation, CABG, preoperative pharmacotherapy, statins.

\section{Introduction}

P

ostoperative atrial fibrillation (POAF) is the most frequently encountered postoperative arrhythmia related to coronary artery bypass graft (CABG) surgery, with a reported incidence between $10 \%$ and $40 \%$. With appearance in the early postoperative period following CABG and a peak incidence between second or third postoperative day, PO$\mathrm{AF}$ is associated with hemodynamic instability, increased morbidity and mortality. ${ }^{1,2}$

The pathophysiology of POAF is not clearly understood, and its mechanism differs from atrial fibrillation in general population in several points. Various pathophysiological mechanisms, such as atrial factors, postoperative inflammation, pericarditis, electrical remodelling, autonomic imbalance, increased vagal tone, atrial incision and perioperative ischaemia, have been proposed to have an important role in the occurrence of POAF. Older age, low ejection fraction and presence of electrolyte imbalance have also been suggested as risk factors for POAF. Poor myocardial protection and atrial ischaemia during cardiopulmonary bypass (CPB) have also been reported as important mechanisms of POAF. The underlying ischaemic mechanism has been discussed in various reports comparing on-pump versus off-pump CABG surgery. ${ }^{1}$

In recent years, off-pump coronary artery bypass grafting has emerged as an alternative method for 
conventional on-pump coronary artery bypass grafting and the advent of off-pump CABG rassed the expectation that there would be a strikingly lower incidence of POAF. However, more recent studies demonstrated that POAF occurred with similar frequencies irrespective of the method of revascularization used, after adjusting for differences in baseline, and perioperative variables. ${ }^{3}$

Risk factors for POAF could be grouped into pre-, intra- and postoperative. Preoperative factors mainly include: sex, age, body mass index, type of coronary artery disease, stage of systolic dysfunction, preoperative AF or myocardial infarction, preoperative echocardiographic parameters and well known risk factors for coronary artery disease: arterial hypertension (HTA), diabetes mellitus (DM), dyslipidemia (HLP), chronic lung disease (COPD), preoperative transient ischemic attack or cerebrovascular insult ( $T I A / C V I)$, peripheral arterial disease (PAD) and smoking. Intraoperative factors are: number, type and location of bypass grafts, time of extracorporeal circulation usage and cross-clamp time. Postoperative factors could be the postoperative use of inotropes and postoperative value of troponin. ${ }^{2}$

Consequently, effective treatment for the prevention of POAF is of vital importance. Numerous pharmacologic strategies attempt to reduce the incidence of POAF. Overall, most reported studies demonstrate a positive effect with a variety of pharmacologic agents either anti-arrhythmic (amiodarone, beta-blockers, digoxin, ACEi/ARBs, calcium-antagonists) or nonantiarrhythmic drugs (non-steroidal antiinflammatory drugs, corticosteroids, statins). To date, however, no single agent or combination of agens have completely eliminated POAF. ${ }^{2}$ Studies of treatments to reduce the risk of POAF have yielded conflicting results.

The aim of this strudy was to investigate the relationship of preoperative pharmacotherapy with the occurrence of POAF in patients undergoing CABG.

\section{Methods}

This retrospective study, conducted from September to December 2014, included 226 consecutive patients without history of prior AF, scheduled for CABG (offpump/on-pump) at Cardiosurgery Clinic, Clinical Centre of Serbia. All patients underwent continuous telemetry for $\geq 5$ postoperative days (until discharge) and POAF was documented using 12-channel electrocardiography. All patients were divided into two groups: 1) POAF patients ( $\mathrm{N} 53 ; 23.5 \%$ ) and 2 ) non-POAF patients (N 173; $76.5 \%)$. In both groups we investigated the influence of preoperative pharmacotherapy (amiodarone, betablockers, digoxin, diuretics, spironolactone, ACEi/ARBs,
Table 1. Differences between the groups considering other preoperative factors

\begin{tabular}{|l|l|l|l|l|}
\hline Variable & $\begin{array}{l}\text { All } \\
\text { n (\%) }\end{array}$ & $\begin{array}{l}\text { POAF } \\
\text { n (\%) }\end{array}$ & $\begin{array}{l}\text { non-POAF } \\
\text { n (\%) }\end{array}$ & p \\
\hline Age (years) & $63.9 \pm 7.9$ & $65.8 \pm 7.3$ & $63.4 \pm 8.0$ & 0.049 \\
\hline Female sex & $54(23.9 \%)$ & $10(18.9 \%)$ & $44(25.4 \%)$ & 0.363 \\
\hline Hypertension & $222(98.2 \%)$ & $50(94.3 \%)$ & $172(99.4 \%)$ & 0.041 \\
\hline Diabetes mellitus & $99(43.8 \%)$ & $19(35.8 \%)$ & $80(46.2 \%)$ & 0.207 \\
\hline Dyslipidemia & $197(87.2 \%)$ & $46(86.8 \%)$ & $151(87.3 \%)$ & 0.544 \\
\hline COPD & $27(11.9 \%)$ & $9(17.0 \%)$ & $18(10.4 \%)$ & 0.226 \\
\hline Stroke/TIA & $22(9.7 \%)$ & $4(7.5 \%)$ & $18(10.4 \%)$ & 0.791 \\
\hline PAD & $44(19.5 \%)$ & $10(18.9 \%)$ & $34(19.7 \%)$ & 1.000 \\
\hline Smoking status & $104(46.0 \%)$ & $22(41.5 \%)$ & $82(47.4 \%)$ & 0.529 \\
\hline
\end{tabular}

COPD- chronic obstructive pulmonary disease; TIA- transient ischemic attack; PAD-

Table 2 Differences between the groups considering medications.

\begin{tabular}{|l|l|l|l|l|}
\hline Variable & $\begin{array}{l}\text { All } \\
\text { n (\%) }\end{array}$ & $\begin{array}{l}\text { POAF } \\
\text { n (\%) }\end{array}$ & $\begin{array}{l}\text { non-POAF } \\
\text { n (\%) }\end{array}$ & $\mathbf{p}$ \\
\hline Amiodarone & $15(6.6 \%)$ & $4(7.5 \%)$ & $11(6.4 \%)$ & 0.756 \\
\hline Beta-blockers & $193(85.4 \%)$ & $44(83.0 \%)$ & $149(86.1 \%)$ & 0.657 \\
\hline Digoxin & $1.0(0.4 \%)$ & $0(0.0 \%)$ & $1(0.6 \%)$ & 1.000 \\
\hline Diuretics & $90(39.8 \%)$ & $22(41.5 \%)$ & $68(39.3 \%)$ & 0.873 \\
\hline Spironolactone & $34(15.0 \%)$ & $10(18.9 \%)$ & $24(13.9 \%)$ & 0.384 \\
\hline ACEi/ARBs & $183(81.0 \%)$ & $45(84.9 \%)$ & $138(79.8 \%)$ & 0.549 \\
\hline Ca antagonists & $57(25.2 \%)$ & $14(26.4 \%)$ & $43(24.9 \%)$ & 0.857 \\
\hline Statins & $189(84.0 \%)$ & $39(73.6 \%)$ & $150(87.2 \%)$ & 0.030 \\
\hline
\end{tabular}

ACEi- angiotensin-converting enzyme inhibitors; ARBs- angiotensin II receptor

Table 3 Differences between the groups considering the use of on-pump or off-pump surgery.

\begin{tabular}{|l|l|l|l|l|}
\hline Variable & $\begin{array}{l}\text { All } \\
\mathbf{n}(\%)\end{array}$ & $\begin{array}{l}\text { POAF } \\
\mathbf{n}(\%)\end{array}$ & $\begin{array}{l}\text { non-POAF } \\
\mathbf{n}(\%)\end{array}$ & $\mathbf{p}$ \\
\hline ON-PUMP surgery & $176(77.9 \%)$ & $39(73.6 \%)$ & $137(79.2 \%)$ & 0.450 \\
\hline OFF-PUMP surgery & $50(22.1 \%)$ & $14(26.4 \%)$ & $36(20.8 \%)$ & 0.450 \\
\hline
\end{tabular}

calcium-antagonists, statins) on the incidence of POAF. The exclusion criteria were severe mitral regurgitation and preoperative AF.

Statistical analysis. The relationship of preoperative pharmacotherapy with the occurrence of POAF was investigated using univariate and multivariable Logistic regression analyses, adjusted for demographic characteristics (age, sex), cardiovascular risk factors (arterial hypertension [HTA], diabetes mellitus [DM], dyslipidemia [HLP], chronic lung disease [COPD], preoperative transient ischemic attack or cerebrovascular insult [TIA/CVI], peripheral arterial disease [PAD] and smoking), and the type of CABG procedure (off-pump, on-pump).

\section{Results}

Of 226 consecutive patients undergoing isolated CABG (mean age: $63.9 \pm 7.9$ years), 54 patients were female (23.9\%). During the in-hospital monitoring 53 patients $(23.5 \%)$ experienced $\geq 1$ episode of POAF. Patients with POAF were older ( $65.8 \pm 7.3$ vs. $63.4 \pm 8.0 ; p=0.049$ ) and less often were taking statins preoperatively 
compared to non-POAF patients ( $\mathrm{n}=39,73.6 \%$ vs. $n=137$, $87.2 \% ; p=0.030$ ). There were no significant differences between the groups considering other preoperative factors or medications in POAF vs. non-POAF patients (Table 1 and Table 2). In addition, there was no difference in the use of on-pump or off-pump surgery in the POAF vs. non-POAF group $(p=0.450)$ (Table 3 ).

In a multivariable analysis, adjusted for demographic characteristics (age, sex), cardiovascular risk factors (HTA, DM, HLP, COPD, preoperative TIA/CVI, PAD and smoking), and the type of CABG procedure (off-pump, on-pump), preoperative statin use was associated with a $60 \%$ risk reduction in POAF incidence (Odds Ratio $0.41 ; 95 \% \mathrm{Cl} 0.19-0.87 ; \mathrm{p}=0.020)$.

\section{Discussion}

In our study $23.5 \%$ of all patients experienced $\geq 1$ episode of POAF. Guenancia et al. reported similar results in their study. They included 100 patients (44.64\%), with all inclusion criteria, underwent Holter ECG monitoring for 7 days, in order to diagnose also silent POAF, which was defined as the occurrence of POAF on the Holter ECG recording in the absence of any mention of $A F$ in the medical file during the first 7 days of the hospital stay, that was analyzed after hospital discharge. In contrast, clinical POAF (whether symptomatic or not) was defined as any AF episode diagnosed by a physician during the hospital stay. Among, them 21 (21\%) developed clinical AF and $13(13 \%)$ developed silent AF as detected by Holter monitoring. ${ }^{4}$

In our study, patients with POAF were older (65.8 57.3$)$. It is well known that the incidence of POAF increases with older age, with a rate of $18 \%$ when age is less than 60 years and $52 \%$ for patients older than 80 years, with an increase of $24 \%$ in the odds ratio of developing POAF for every five-year increase in age and a plateau after the age of 80 . Fibrosis and dilatation of the atria have been shown to increase with age, with a loss of side-to-side coupling among atrial myocardial cells and consequent slow atrial electrical conduction, which may facilitate the development of atrial fibrillation. $5,6,7,8$

In our study $81.1 \%(n=43)$ of male patients and $18.9 \%(n=10)$ of female patients had POAF. Sex-based differences in AF occurrence include differences in the expression of ion channels, hormonal effects on autonomic tone, and in myocardial architecture or fibre orientation. ${ }^{9,10,11,12}$

There were no significant differences between the groups considering other preoperative factors (HTA, DM, COPD, preoperative TIA/CVI, PAD and smoking) in POAF vs. non-POAF patients. Arterial hypertension was present in $60 \%$ of patients with $\mathrm{AF}$ in the Framingham Study. ${ }^{13}$ Hypertension leads to myocardial hypertrophy, with foci of myocardial fibrosis, and favours the dispersion of atrial refractoriness. ${ }^{14,15,16,17}$ Diabetes mellitus (DM) is another well known predictor for POAF in surgical population as well as in the general one. ${ }^{18}$ Autonomic neuropathy seems to be responsible for $A F$ in diabetic patients-it blunts parasympathetic activity, allowing for a higher sympathetic excess. ${ }^{18,19,20}$ Indeed, removal of parasympathetically innervated aortic fat has been demonstrated to increase the risk of developing AF. ${ }^{21}$ Similarly, smoking interferes with the hyperadrenergic state registered after surgical trauma. Smokers have a higher adrenergic tolerance and are protected against POAF. ${ }^{22}$ Chronic obstructive pulmonary disease (COPD) may result in arterial hypoxia due to associated ventilation perfusion mismatch. ${ }^{23}$ Patients with COPD have frequent premature atrial contractions that favour $\mathrm{AF}$ development. ${ }^{23,} 24,25$ Transient ischemic attack (TIA)/ cerebrovascular insult (CVI) and peripheral artery disease (PAD) are also well known risk factors for AF/POAF.

We found no significant difference between the groups in our study considering the preoperative use of amiodarone. Amiodarone has been proved to be useful in the prevention of POAF. Daud et al. randomized 124 patients undergoing elective cardiac surgery to receive oral amiodarone $(600 \mathrm{mg} /$ day prior and $200 \mathrm{mg} /$ day after surgery) or placebo for 7 days prior the surgery until the discharge. ${ }^{26}$ The use of amiodarone was associated with statistically significant $(p=0.03)$ decrease in POAF incidence (23\%) compared to placebo (42\%). Redle et al. evaluated 150 patients undergoing CABG in a randomized double blind controlled trial, comparing amiodarone with placebo. ${ }^{27}$ In amiodarone group, $2000 \mathrm{mg}$ of the drug were given in a graduated dosing schedule and then the patients received $400 \mathrm{mg} /$ day beginning on the first postoperative day and continued for seven days. The incidence of POAF was not affected by the prophylactic oral amiodarone and there was no difference between the two groups $(p=0.3)$. A major study limitation was that the concomitant use of digoxin, calcium-antagonist and beta-blocker was not controlled.

Also, in our study there was no significant difference between study groups considering preoperative use of beta-blockers, but all identified meta-analyses demonstrated that beta-blockers significantly reduced the incidence of POAF. $28,29,30,31,32$ Andrews et al. showed that the incidence of POAF decreased from $34 \%$ to $8,7 \%$ in patients received beta-blockers. In another meta-analysis of Kowey et al., the decrease in incidence of AF was from $20 \%$ to $8,7 \%{ }^{33}$ Crystal et al performed the largest meta-analysis based on 27 randomised controlled trials that included 3.840 patients. Especially, the control group presented an incidence of AF approximately $33 \%$, while notably patients receiving beta-blockers had an incidence of $19 \%$ [23]. Ferguson et al., in another large retrospective analysis of the Thoracic Surgeons surgical database that included 629.877 patients, observed the morbidity and mortality rate associated with the perioperative use of beta-blockers. ${ }^{34}$ They revealed a reduction in mortality rate from $3.4 \%$ to $2.8 \%$ in patients that received peri-operatively beta-blockers. Numerous randomized trials have been conducted so as to evaluate the effectiveness of beta-blockers in the prevention of AF. Lucio et al. randomized 200 patients underwent isolated CABG to receive either metoprolol or no drug. ${ }^{35}$ Metoprolol was given orally adjusted to maintain optimal heart rate and started from the $12^{\text {th }}$ hour to the $7^{\text {th }}$ postoperative day or hospital discharge. POAF and atrial flutter occurred at $24 \%$ in control versus $11 \%$ in metoprolol group $(p=0.02)$. 
Several studies compared the efficacy of intravenous (i.v.) or oral beta-blocker as well as different types of beta-blocker. Halonen et al., in an attempt to compare the intravenous with the oral use of metoprolol, randomized 240 patients who underwent first on pump CABG, aortic valve replacement or combined aortic valve replacement and CABG. ${ }^{36}$ In both groups, the metoprolol administration was based on heart rate for a 48 hour period. POAF presented a significant decrease $(p=0.036)$ in intravenous group $(16.8 \%)$ compared to oral group (28.1\%). It should be mentioned that patients at risk to develop complications associated with intravenous metoprolol were excluded.

Moreover, comparison of the effectiveness between metoprolol and carvedilol has also been performed. Acikel et al. randomized 110 patients scheduled for elective CABG to receive either metoprolol (50 $\mathrm{mg} \mathrm{td}$ ) or carvedilol $(12,5 \mathrm{mg} \mathrm{td}) .{ }^{37}$ Therapy was started 3 days prior to surgery and continued in the postoperative period with mean dosages of carvedilol (13 mg daily) and metorpolol $(58 \mathrm{mg} /$ day) in corresponding groups. POAF had an incidence of $36.4 \%$ in metorpolol compared to $16 \%$ in carvedilol group $(p=0.029)$. Hafgjoo et al. randomized 120 patients undergoing CABG to receive metoprolol or carvedilol..$^{38}$ In this study, the therapy was started 10 days prior the surgery and initiated with an oral dose of carvedilol $6.25 \mathrm{mg}$ and $25 \mathrm{mg}$ metoprolol twice daily respectively. Then the dosage was increased until the maximum tolerated dose. The incidence of POAF was significantly reduced $(p=0.022)$ in carvedilol $(15 \%)$ compared with metoprolol (33\%) group. The study presented several limitations: it was a single centre study consisted of small number of patients and thus, inflammation markers such as CRP had not been measured, despite the hypothesis that anti-inflammatory properties of carvedilol may have contributed to increased efficacy.

Kaireviciute et al. showed that digoxin does not show any benefit for POAF prophylaxis (OR $0.97,95 \% \mathrm{Cl} 0.62$ $-1.49)^{39}$, just like in our study. A subgroup analysis in a meta-analysis of calcium-antagonists found that nondihydropyridines significantly suppressed post-surgery supraventricular arrhythmias (OR $0.62,95 \% \mathrm{Cl} 0.41-$ $0.93)$, but with a high heterogeneity $(p=0.03) .{ }^{40}$ In our study there was not any difference between groups considering the preoperative use of calcium-antagonists. Several studies compared atenolol with other regiments such as digitalis or propafenone. Yazicioglu et al. randomized 160 patients underwent CABG into 4 groups of treatment: a. digoxin and atenolol, b. digoxin, c. atenolol, d. placebo. ${ }^{41}$ The combination of atenolol and digitalis (5\%) decreased significantly POAF compared with placebo $(25 \%, p=0.012)$ but there was no significant difference compared to digoxin or atenolol alone $(17.9 \%, 15.4 \% \mathrm{p}=0.087)$. Merrick et al., in SPPAF trial, allocated randomly 207 patients underwent non-emergency cardiac surgery, to receive orally either propafenone $300 \mathrm{mg}$ twice daily or atenolol $50 \mathrm{mg}$ once daily from the first until the $7^{\text {th }}$ postoperative day or until an end point (AF appearance) was reached..$^{42}$ The atenolol and the propafenone presented equal efficacy $(10,7 \%$ vs. $12 \%$ ) in the prevention of AF.
Chin et al. investigated whether preoperative angiotensin-converting enzyme inhibitor (ACEi) or angiotensin receptor blocker (ARBs) use affected the incidence of POAF in patients undergoing off-pump CABG surgery. They concluded that ACEi or ARBs, ACEi alone, and ARBs alone did not favorably influence the occurrence of POAF in patients undergoing off-pump procedure..$^{43} \mathrm{In}$ our study we have got the same results.

There was no significant difference between our study groups considering preoperative use of diuretics and spironolactone. Bandeali et al. evaluated the influence of preoperative diuretic use in three groups of patients-isolated CABG, CABG plus valve surgery, isolated valve surgery on the appearance of POAF and they concluded that its associated with an increased incidence of new-onset atrial fibrillation (POAF). ${ }^{44}$

Finally, we found that preoperative statin use was associated with a $60 \%$ risk reduction in POAF incidence. The antiarrhythmic mechanism of statins can possibly be explained by their effects on inflammation $45,46,47,48$, antioxidant effects ${ }^{49,50}$, antiarrhythmic effects due to ion channel stabilization ${ }^{51}$, a role in extracellular matrix modulation $^{52}$, an inhibition of synthesis of isoprenoids that are significant for the posttranslational modification of such signalling molecules as Rho, Rac, and Ras ${ }^{50}$, and an ability to reverse angiotensin II-mediated atrial structural remodeling. ${ }^{53}$ Ozaydin et al. reported that pre-treatment with statins was protective against the development of POAF (on Kaplan-Meier analysis $\mathrm{P}=$ 0.01 ), but also shortened the duration of POAF episodes $(P=0.0001) .{ }^{54}$ The advantage of statin pre-treatment in the suppression of POAF incidence after elective CABG may not depend on type, dose, or duration of use..$^{55}$ Nonetheless, negative studies showing no benefit of statins on POAF also exist. For example, pre-treatment with statin prior to cardiac surgery did not show any significant benefit for reducing the risk in the development of POAF ${ }^{56}$ However, this study was conducted retrospectively, and patients received different statins, variable doses were used, and there were incomplete data on the duration of statin treatment prior to cardiac surgery. The first randomized, placebo-controlled trial on statin pretreatment for the reduction of POAF incidences was the ARMYDA-3 (Atorvastatin for Reduction of Myocardial Dysrhythmia after cardiac surgery) trial ${ }^{45}$, which showed a significant decrease in POAF occurrences after pre-treatment with atorvastatin. Moreover, hospital length of stay was shorter in the atorvastatin group compared with placebo $(P=0.001)$. Of note, there was significantly higher post-operative peak Creactive protein levels in AF patients compared with those who remained in SR $(P=0.01){ }^{45}$; however, the ARMYDA-3 trial did not find any statistical association between statin use and plasma C-reactive protein levels. Thus, pretreatment with statin seems to be useful particularly prior to the CABG surgery, despite the small incidences of rhabdomyolysis caused by high doses of statin. ${ }^{57} \mathrm{~A}$ meta-analysis of six randomized studies on the impact of statin treatment on the suppression of $A F$ included two studies with POAF and found that statins were more beneficial in secondary AF prevention rather 
in primary prevention and their effect did not appear to be dose-related. ${ }^{58}$

\section{Conclusion}

Our results suggest that preoperative use of statins may reduce the incidence of POAF with a $60 \%$ risk reduction in POAF incidence in patients undergoing isolated CABG. We also found that there was no difference in the use of on-pump or off-pump surgery in the POAF vs. non-POAF group.

\section{References}

1. Sahin I, Özkaynak B, Karabulut A, et al. Impact of coronary collateral circulation and severity of coronary artery disease in the development of postoperative atrial fibrillation. Interact Cardiovasc Thorac Surg 2014;19:394-397.

2. Koniari I, Apostolakis E, Rogkakou C, et al. Pharmacologic prophylaxis for atrial fibrillation following cardiac surgery: a systematic review. J Cardiothorac Surg 2010;30: 125:121.

3. Enc $Y$, Ketenci B, Ozsoy D, et al. Atrial fibrillation after surgical revascularization: is there any difference between on-pump and off-pump? Eur J Cardiothorac Surg 2004;26:1129-1133.

4. Guenancia C, Pujos C, Debomy F, et al. Incidence and Predictors of New Onset Silent Atrial Fibrillation after Coronary Artery Bypass Graft Surgery. Biomed Res Int 2015; 2015:703685.

5. Creswell LL, Schuessler RB, Rosenbloom M, et al. Hazards of postoperative atrial arrhythmias. Ann Thorac Surg 1993;56:539-549.

6. Mathew JP, Parks R, Savino JS, et al. Atrial fibrillation following coronary artery bypass graft surgery: predictors, outcomes, and resource utilization: Multicenter Study of Perioperative Ischemia Research Group. JAMA 1996;276:300-306.

7. Aranki SF, Shaw DP, Adams DH, et al. Predictors of atrial fibrillation after coronary artery surgery. Current trends and impact on hospital resources. Circulation 1996;94:390-397.

8. Spach MS, Dolber PC. Relating extracellular potentials and their derivatives to anisotropic propagation at a microscopic level in human cardiac muscle. Evidence for electrical uncoupling of side-to-side fiber connections with increasing age. Circ Res 1986;58:356-371.

9. Barasch E, Gottdiener JS, Aurigemma G, et al. Association between elevated fibrosis markers and heart failure in the elderly/ clinical perspective. Circulation Heart Fail 2009;2:303-310.

10. Li D, Fareh S, Leung TK, et al. Promotion of atrial fibrillation by heart failure in dogs: atrial remodeling of a different sort. Circulation 1999;100:87-95.

11. Kopecky SL, Gersh BJ, McGoon MD, et al. The natural history of lone atrial fibrillation: a population-based study over three decades. N Engl J Med 1987;317:669-674.

12. Cooke J, Creager M, Osmundson P, et al. Sex differences in control of cutaneous blood flow. Circulation 1990;82:1607-1615.

13. Benjamin EJ, Levy D, Vaziri SM, et al. Independent risk factors for atrial fibrillation in a population-based cohort: the Framingham heart study. JAMA 1994;271:840-844.

14. McLenachan JM, Dargie HJ. Ventricular arrhythmias in hypertensive left ventricular hypertrophy. Relationship to coronary artery disease, left ventricular dysfunction, and myocardial fibrosis. Am J Hypertension 1990;3:735-740.

15. Peters NS, Green CR, Poole-Wilson PA, et al. Reduced content of connexin43 gap junctions in ventricular myocardium from hypertrophied and ischemic human hearts. Circulation 1993;88:864-875.

16. L'Allier PL, Ducharme A, Keller P-F, et al. Angiotensin converting enzyme inhibition in hypertensive patients is associated with a reduction in the occurrence of atrial fibrillation. J Am Coll Cardiol 2004;44:159-164.
17. Topol EJ, Traill TA, Fortuin NJ. Hypertensive hypertrophic cardiomyopathy of the elderly. N Engl J Med 1985;312:277-283.

18. Hurt C, Coisne A, Modine T. et al. Contrasting effects of diabetes and metabolic syndrome on post-operative atrial fibrillation and in-hospital outcome after cardiac surgery. Int J Cardiol 2013;167:2347-2350.

19. Kannel WB, Abbott RD, Savage DD, et al. Epidemiologic features of chronic atrial fibrillation: the Framingham study. N Engl J Med 1982;306:1018-1022.

20. Movahed MR, Hashemzadeh M, Jamal MM. Diabetes mellitus is a strong, independent risk for atrial fibrillation and flutter in addition to other cardiovascular disease. Int J Cardiol 2005;105:315-318.

21. Cummings JE, Gill I, Akhrass R, et al. Preservation of the anterior fat pad paradoxically decreases the incidence of postoperative atrial fibrillation in humans. J Am Coll Cardiol 2004;43: 994-1000.

22. Mariscalco G, Engström KG. Are current smokers paradoxically protected against atrial fibrillation after cardiac surgery? Nicotine Tob Res 2009;11:58-63.

23. Kuralay $E$, Cingöz F, Kiliç $S$, et al. Supraventricular tachyarrhythmia prophylaxis after coronary artery surgery in chronic obstructive pulmonary disease patients (early amiodarone prophylaxis trial). Eur J Cardiothorac Surg 2004;25:224-230.

24. Crosby LH, Pifalo WB, Woll KR, et al. Risk factors for atrial fibrillation after coronary artery bypass grafting. Am J Cardiol 1990;66:1520-1522.

25. Rubin DA, Nieminski KE, Reed GE, et al. Predictors, prevention, and long-term prognosis of atrial fibrillation after coronary artery bypass graft operations. J Thorac Cardiovasc Surg 1987;94: 331-335.

26. Daoud EG, Strickberger SA, Man KC, et al. Preoperative amiodarone as prophylaxis against atrial fibrillation after heart surgery. N Engl J Med 1997;337:1785-1791.

27. Redle JD, Khurana S, Marzan R, et al. Prophylactic oral amiodarone compared with placebo for prevention of atrial fibrillation after coronary artery bypass surgery. Am Heart J 1999;138:144-150.

28. Hammermeister KE, Morrison DA. Coronary bypass surgery for stable angina and unstable angina pectoris. Cardiol Clin 1991;9:135-155.

29. Hayashida N, Shojima T, Yokokura Y, et al. P-wave signal-averaged electrocardiogram for predicting atrial arrhythmia after cardiac surgery. Ann Thorac Surg 2005;79:859-864.

30. Fleming GA, Murray KT, Yu C, et al. Milrinone use is associated with postoperative atrial fibrillation after cardiac surgery. Circulation 2008;118:1619-1625.

31. Smith PK, Buhrman WC, Levett JM, et al. Supraventricular conduction abnormalities following cardiac operations. A complication of inadequate atrial preservation. J Thorac Cardiovasc Surg 1983;85:105-115.

32. Rao V, Ivanov J, Weisel RD, et al. Predictors of low cardiac output syndrome after coronary artery bypass. J Thorac Cardiovasc Surg 1996;112:38-51.

33. Andrews TC, Reimold SC, Berlin JA, et al. Prevention of supraventricular arrhythmias after coronary artery bypass surgery. A meta-analysis of randomized control trials. Circulation 1991;84(5 Suppl): III236-244.

34. Ferguson TB Jr, Coombs LP, Peterson ED, et al. Preoperative betablocker use and mortality and morbidity following CABG surgery in North America. JAMA 2002;287: 2221-2227.

35. Lúcio Ede A, Flores A, Blacher C, et al. Effectiveness of metoprolol in preventing atrial fibrillation and flutter in the postoperative period of coronaryartery bypass graft surgery. Arq Bras Cardiol 2004;82: 42-46, 37-41.

36. Halonen J, Hakala T, Auvinen T, et al. Intravenous administration of metoprolol is more effective than oral administration in the prevention of atrial fibrillation after cardiac surgery. Circulation 2006;114 (1 Suppl):I1-4. 
37. Acikel S, Bozbas H, Gultekin B, et al. Comparison of the efficacy of metoprolol and carvedilol for preventing atrial fibrillation after coronary bypasssurgery. Int J Cardiol 2008;126:108-113.

38. Haghjoo M, Saravi M, Hashemi MJ, et al. Optimal beta-blocker for prevention of atrial fibrillation after on-pump coronary artery bypass graft surgery:carvedilol versus metoprolol. Heart Rhythm 2007;4:1170-1174.

39. Kowey PR, Taylor JE, Rials SJ, et al. Meta-analysis of the effectiveness of prophylactic drug therapy in preventing supraventricular arrhythmia early after coronary artery bypass grafting. Am J Cardiol 1992;69:963-965.

40. Wijeysundera DN, Beattie WS, Rao V, et al. Calcium antagonists reduce cardiovascular complications after cardiac surgery: a meta-analysis. J Am Coll Cardiol 2003;41:1496-1505.

41. Yazicioglu L, Eryilmaz S, Sirlak M, et al. The effect of preoperative digitalis and atenolol combination on postoperative atrial fibrillation incidence. Eur J Cardiothorac Surg 2002;22: 397-401.

42. Merrick AF, Odom NJ, Keenan DJ, et al. Comparison of propafenone to atenolol for the prophylaxis of postcardiotomy supraventriculartachyarrhythmias: a prospective trial. Eur J Cardiothorac Surg 1995;9:146-149.

43. Chin JH, Lee EH, Son HJ, et al. Preoperative treatment with an angiotensin-converting enzyme inhibitor or an angiotensin receptor blocker has no beneficial effect on the development of newonset atrial fibrillation after off-pump coronary artery bypass graft surgery. Clin Cardiol 2012;35:37-42.

44. Bandeali SJ, Kayani WT, Lee VV, et al. Association between preoperative diuretic use and in-hospital outcomes after cardiac surgery. Cardiovasc Ther 2013;31:291-297.

45. Patti G, Chello M, Candura D, et al. Randomized trial of atorvastatin for reduction of postoperative atrial fibrillation in patients undergoing cardiac surgery: results of the ARMYDA-3 (Atorvastatin for Reduction of MYocardial Dysrhythmia After cardiac surgery) study. Circulation 2006;114:1455-1461.

46. Chello M, Carassiti M, Agro` $F$, et al. Simvastatin blunts the increase of circulating adhesion molecules after coronary artery bypass surgery with cardiopulmonary bypass. J Cardiothorac Vasc Anesth 2004;18:605-609.
47. Chello M, Mastroroberto P, Patti G, et al. Simvastatin attenuates leukocyte-endothelial interactions after coronary revascularization with cardiopulmonary bypass. Heart 2003;89:538-543

48. Chello M, Patti G, Candura D, et al. Effects of atorvastatin on systemic inflammatory response after coronary artery bypass surgery. Crit Care Med 2006;34:660-667.

49. Bonetti PO, Lerman LO, Napoli C, et al. Statin effects beyond lipid lowering: are they clinically relevant? Eur Heart J 2003;24:225-248.

50. Shishehbor MH, Brennan ML, Aviles RJ, et al. Statins promote potent systemic antioxidant effects through specific inflammatory pathways. Circulation 2003;108:426-431.

51. Pound EM, Kang JX, Leaf A. Partitioning of polyunsaturated fatty acids, which prevent cardiac arrhythmias, into phospholipid cell membranes. J Lipid Res 2001;42:346-351.

52. Marin F, Pascual DA, Rolda'n V, et al. Statins and postoperative risk of atrial fibrillation following coronary artery bypass grafting. Am J Cardiol 2006;97:55-60.

53. Tsai C-T, Lai L-P, Kuo K-T, et al. Angiotensin II activates signal transducer and activators of transcription 3 via Rac 1 in atrial myocytes and fibroblasts: implication for the therapeutic effect of statin in atrial structural remodeling. Circulation 2008;117:344-355.

54. Ozaydin M, Dogan A, Varol E, et al. Statin use before by-pass surgery decreases the incidence and shortens the duration of postoperative atrial fibrillation. Cardiology 2007;107:117-121.

55. Mariscalco G, Lorusso R, Klersy $C$, et al. Observational study on the beneficial effect of preoperative statins in reducing atrial fibrillation after coronary surgery. Ann Thorac Surg 2007;84:1158-1164.

56. Virani SS, Nambi V, Razavi M et al. Preoperative statin therapy is not associated with a decrease in the incidence of postoperative atrial fibrillation in patients undergoing cardiac surgery. Am Heart J 2008; 155: 541-546.

57. Harper CR, Jacobson TA. The broad spectrum of statin myopathy: from myalgia to rhabdomyolysis. Curr Opin Lipidol 2007; 18: 401-408.

58. Fauchier L, Pierre B, de Labriolle A et al. Antiarrhythmic effect of statin therapy and atrial fibrillation. J Am Coll Cardiol 2008 ; 51: 828-835

\section{Sažetak}

\section{Uticaj preoperativne medikamentne terapije na pojavu postoperativne atrijalne fibrilacije kod hirurški revaskularizovanih koronarnih bolesnika}

Milica V. Vukicević ${ }^{1}$, Svetozar Putnik ${ }^{2,3}$, Tatjana S. Potpara ${ }^{1,3}$.

${ }^{1}$ Klinika za kardiologiju, Klinički centar Srbije, ${ }^{2}$ Klinika za kardiohirurgiju, Klinički centar Srbije, ${ }^{3}$ Medicinski fakultet, Univerzitet u Beogradu, Srbija.

Uvod: Postoperativna atrijalna fibrilacija (POAF) je najčešća aritmija nakon by-pass hirurgije. Dosadašnjim studijama dobijeni su oprečni rezultati o uticaju preoperativne medikamentne terapije na pojavu POAF. U ovoj studiji ispitivali smo povezanost preoperativne medikamentne terapije sa POAF nakon izolovane hirurške revaskularizacije miokarda.

Metod: Retrospektivnom studijom obuhvaćeno je 226 konsekutivnih bolesnika bez prethodne AF, hospitalizovanih radi planirane by-pass hirurgije od septembra do decembra 2014. Svi bolesnici su praćeni kontinuiranom telemetrijom najmanje pet postoperativnih dana, a POAF je dokumentovana davanestokanalnom elektrokardiografijom. Koristeći uni- i multivarijantnu logističku regresiju (prilagođena za demografske karakteristike, kardiovaskularne faktore rizika, tip by-pass operacije) ispitali smo povezanost preoperativne farmakoterapije sa pojavom POAF.

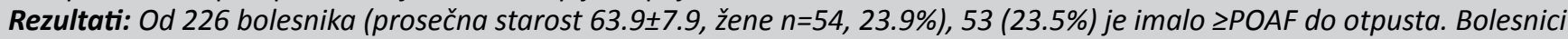
sa POAF bili su stariji (65.8 \pm 7.3 vs. $63.4 \pm 8.0 ; p=0.049)$ i preoperativno su ređe koristili statine u poređenju sa onima kod kojih nije registrovana POAF ( $n=39,73.6 \%$ vs. $n=137,87.2 \%$; $p=0.030)$. U ovoj studiji nismo našli signifikantnu razliku imeđu grupa u odnosu na ostale preoperativne faktore (npr. arterijska hipertenzija, dijabetes melitus, hronična opstruktivna bolest pluća), ili preoperativnu primenu amiodarona, beta-blokatora, digoksina, diuretika, spironolaktona, inhibitora angiotenzin konvertujućeg enzima ili angiotenzin II receptora, kao ni kalcijumskih antagonista. Multivarijantna analiza je pokazala da je preoperativna primena statina povezana sa redukcijom POAF (Odds Ratio 0.41; 95\% Cl 0.19-0.87; $p=0.020$ ). Nije registrovana značajna razlika u pojavi POAF u odnosu na tip hirurške revaskularizacije $(p=0.450)$.

Zaključak: Ovom studijom ustanovili smo da preoperativna primena statina može smanjiti incidencu POAF kod bolesnika nakon izolovane by-pass kardiohriruške operacije.

Ključne reči: postoperativna atrijalna fibrilacija, by-pass, peoperativna farmakoterapija, statini. 